\title{
Charles-Alexandre Lesueur in Philadelphia: His Remarkable Contributions to Natural History and Scientific Illustration
}

\author{
Charles-Alexandre Lesueur à Philadelphie: ses contributions \\ remarquables à l'histoire naturelle et à l'illustration scientifique
}

\author{
John R. Dolan ${ }^{1}$ \\ ${ }^{1}$ Sorbonne Université, CNRS UMR 7093, Laboratoire d'Océanographie de Villefranche-sur-Mer, Station Zoologique, \\ 06230 Villefranche-sur-Mer, France; dolan@obs-vlfr.fr.
}

\begin{abstract}
Here the nearly forgotten contributions of Charles-Alexandre Lesueur (1778-1846) to natural history during his stay in Philadelphia are reviewed. He was a self-taught artist and naturalist whose first occupation was that of an illustrator working for Nicolas Baudin, the commander of a Napoleonic expedition to explore the Austral regions in the early 1800's. Through his work with the naturalist François Péron, both during and after the expedition, he became a reputed naturalist in his own right. Following the demise of Péron, Lesueur traveled to America in 1815 as an assistant for William MacLure, a geological explorer and philanthropist. Although his contract was for but two years, Lesueur resided in North America from 1816 to 1837. He first lived in Philadelphia, from 1816 to 1825, and there he made his critical contributions to the establishment of the one of the first and major societies of natural history in America and its journal, the Journal of the Academy of Natural Sciences of Philadelphia. During this time, Lesueur published on a wide variety of taxa, created important contacts for the Academy of Natural Sciences of Philadelphia with renowned French naturalists, provided illustrations for other naturalists, and even aided in the printing of the journal. Although Lesueur is recognized as one of the key figures of science in 19th century America, his American scientific work is actually little known. This illustrated essay is an effort to shine a light on his neglected natural history work and his striking scientific illustrations from his time in Philadelphia.
\end{abstract}

KEYWORDS. history of natural history, history of science, scientific illustration, scientific societies.

\section{Introduction}

Charles-Alexandre Lesueur was, in chronological order, an artist, an explorer, and a naturalist. Most of his substantial contributions to natural history date from his mid-life period in America. However, the existing and relatively large literature on Lesueur deals almost exclusively with his artwork. Scant attention has been paid to his contributions to natural history, especially in America. For example, the monographs of Hamy (1904) and Loir (1920), both devoted to Lesueur's period in America, contain only copies of his landscape sketches and provide little more than an incomplete bibliography of his scientific articles from the period. Similarly, the richly illustrated book on Lesueur's life of Baglione and Crémière (2016) "Charles-Alexandre Lesueur, Painter and Naturalist: a Forgotten Treasure", while otherwise quite admirable, includes no illustrations from any of his scientific publications. From these accounts and others on Lesueur as a naturalist illustrator (e.g. Petit 1990, Blum 1993), one would not guess that Charles-Alexandre Lesueur is actually considered a major figure in the development of science in America in the 19th century. He was described as one of the pioneers of science in America (Youmans 1896), one of the "greatest American naturalists" (Wenrich 1955), among the "great figures of American science" (Struik 1959), a pioneer ichthyologist (Meyers 1964), and more precisely given the 9th place of the top 20 American ichthyologists (Jackson \& Kimler 1999). Lesueur's contributions were even noted early on by Cuvier himself in his monographic work on fish (Cuvier \& Valenciennes 1828). Despite these periodic accolades, an account of his contributions to natural history during his period in America, specifically his scientific production and his activity in the Academy of Natural Sciences of 
Philadelphia, has not previously been attempted. Indeed, one could say that the Philadelphia period in Lesueur's life, $40 \%$ of his time in America, has been largely and curiously neglected. For example, in Loir's monograph on Lesueur's time in America, only 9 of 82 text pages concern the Philadelphia period (Loir 1920). Similarly, in Hamy's monographic work on Lesueur's time in America of over 111 text pages, only 9 are given to the Philadelphia period (Hamy 1904). Here I try to draw attention to his scientific contributions and striking scientific illustrations of the period. First a biography of Lesueur's remarkable life is given followed by an account of his years in Philadelphia, his contributions to natural history overall, and to the development of the Academy of Natural Sciences of Philadelphia in particular. Some examples of his scientific illustrations will be given to show their quality and the breadth of subjects treated.

\section{Biography of Charles-Alexandre Lesueur (1778-1846)}

The following sketch of his life is, unless otherwise noted, is based largely on the 2016 account of Baglione and Crémière. He was born into a military family, but unlike his two older brothers, he did not pursue a military career. At the age of 21 he joined Nicolas Baudin's Expedition (1800-1804) to explore the Austral regions. It was an expedition sent by Napoleon Bonaparte, for reasons both political and scientific (Martin 1998). Lesueur was ostensibly a member of the crew, an "assistant gunner", of the Géographe, one of the two expedition ships. However, he and another "assistant gunner", Nicolas-Martin Petit, were assigned by Baudin to be the illustrators of his personal journal. While Petit had trained as an artist, there is no evidence that Lesueur had any particular art experience or training. Exactly how and when Baudin discovered his Lesueur's talent for drawing is unknown. However, by the time the Expedition made its first port call in the Canaries, a few weeks after departure, Baudin's journal states that Lesueur's drawings left little to be desired (Baudin 2000).

The expedition included a large scientific staff of astronomers, botanists, zoologists, official artists, etc. Among the scientific staff was François Péron, at 25 years old, a former soldier, former medical student, and student of Natural History who had managed to secure a last minute appointment as zoologist and anthropologist (Duyker 2006). By the time the expedition reached Australian waters, between desertions and deaths among the scientific crew, Péron was the only zoologist and Lesueur and Petit were the only artists remaining. Lesueur and Péron formed a close bond during the voyage and became a scientist-illustrator team that was entirely responsible for the very large amount zoological work carried out. Upon their return to France, Péron was charged with producing a multi-volume report on the expedition with illustrations by Lesueur and Petit. They were granted imperial state pensions to allow them to work on the report and the collections. Péron and Lesueur stayed together in Paris in lodgings close to the Natural History Museum. The first volume of the report was published in 1807. It was followed by the publication of an "atlas" of illustrations by Lesueur and Petit, in 1811. Lesueur's illustrations of organisms, landscapes, and instruments in the "atlas" firmly established his reputation as a talented artist (Figure 1). 


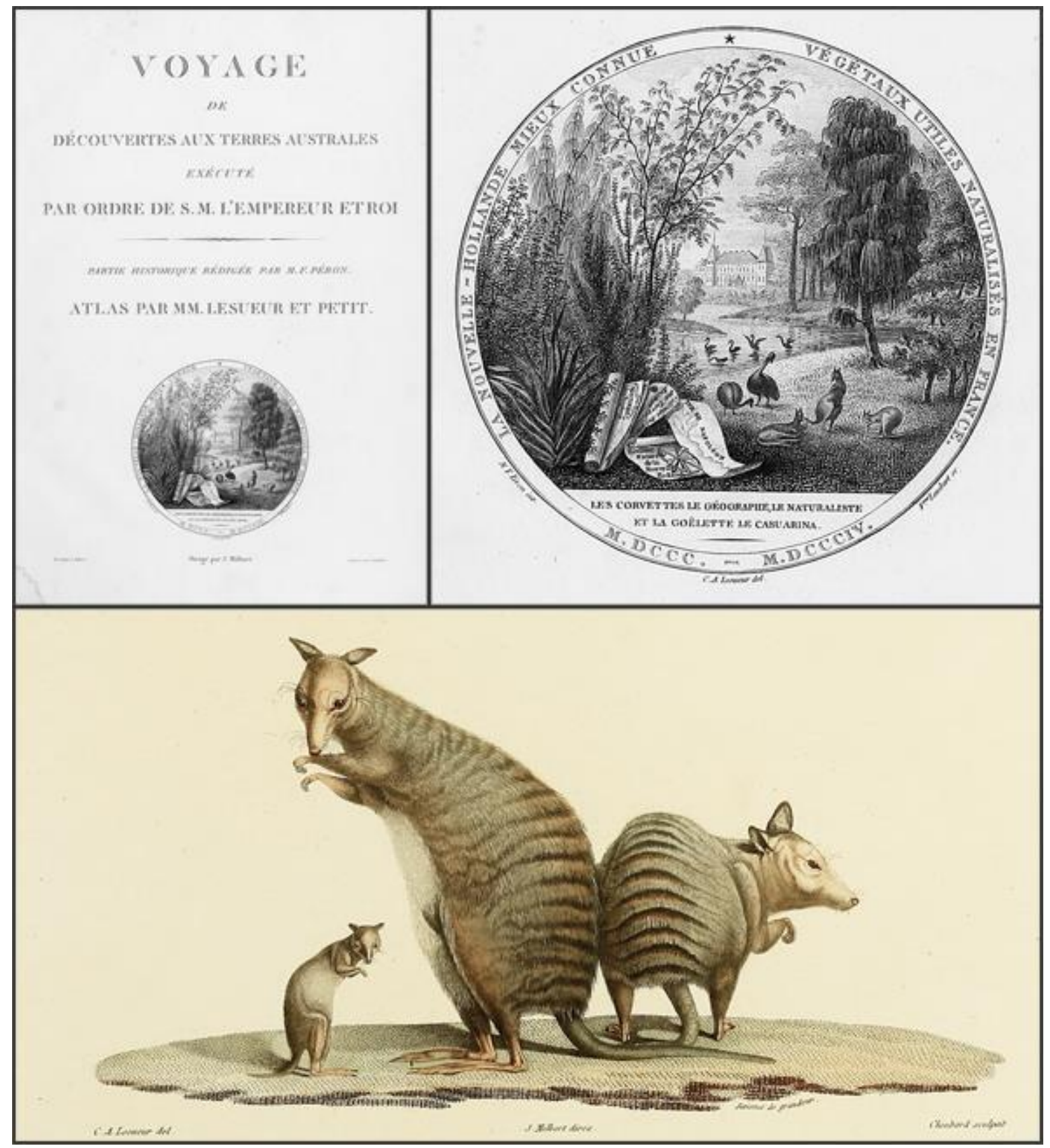

Figure 1. Lesueur's artistic reputation was established through his illustrations in the 'atlas part 1' of "Voyages de Découvertes aux Terres Australes", the reports on the Baudin Expedition (1800-1804) published in 1811. Top left panel shows the cover of the 'Atlas', containing the illustrations for the first text volume. The top left panel shows the remarkable detail of the cover illustration by Lesueur. It depicts the Australian plants and animals brought back by Péron and Lesueur to join the black swans in the garden of Malmaison, Josephine Bonaparte's mansion. The lower panel shows Lesueur's drawing of kangaroos from the Atlas.

Péron developed steadily worsening lung problems on his return to France, likely tuberculosis. By late 1808, his doctors recommended a long stay in the warmer climate of southern France. Péron and Lesueur traveled to Nice and there stayed from February to August 1809. They occupied themselves with frequent sampling expeditions to gather invertebrates in the coastal waters, "trying to discover new species", which they did. They also made friends among the naturalists of Nice, for example, Antoine Risso, the pioneer ichthyologist. Lesueur did some of the sampling alone when Péron's condition worsened, likely his first experiences as an independent naturalist. They returned to Paris but by October 1810 when it was clear that Péron was facing his final days, he left Paris with Lesueur to be in his family home with his sister in Cérilly. Péron died on October 14, 1810 at 
the age of 35 holding Lesueur's hand, and leaving Lesueur, according to a eulogy of Péron, "alone in the world" (Deleuz 1816).

From 1810 to 1815 , Lesueur divided his time between Paris and his native Le Havre. In 1813 he published his first article without Péron. In it he described new species found during the stay in Nice. The plate accompanying the article (Figure 2) showed a large invertebrate 'the Venus Belt' found in the Bay of Villefranche. According to the inscription, the plate was drawn and engraved by Lesueur indicating that he had taught himself engraving. The following year he published his first description of fish (Lesueur 1814), one he named for Risso, again based on collections made during the stay in Nice, again including a plate he engraved. It was the first of what would be many works on fish, a group Péron never worked on. In March 1814 Lesueur was named a member of the La Sociéte Philomatique, a prestigious scientific society generally considered as the 'waiting room' for the Academy of Sciences in the early 19th century (Chappy 2009). He was then by 1814, undeniably a naturalist of some repute and adept at both drawing and engraving.

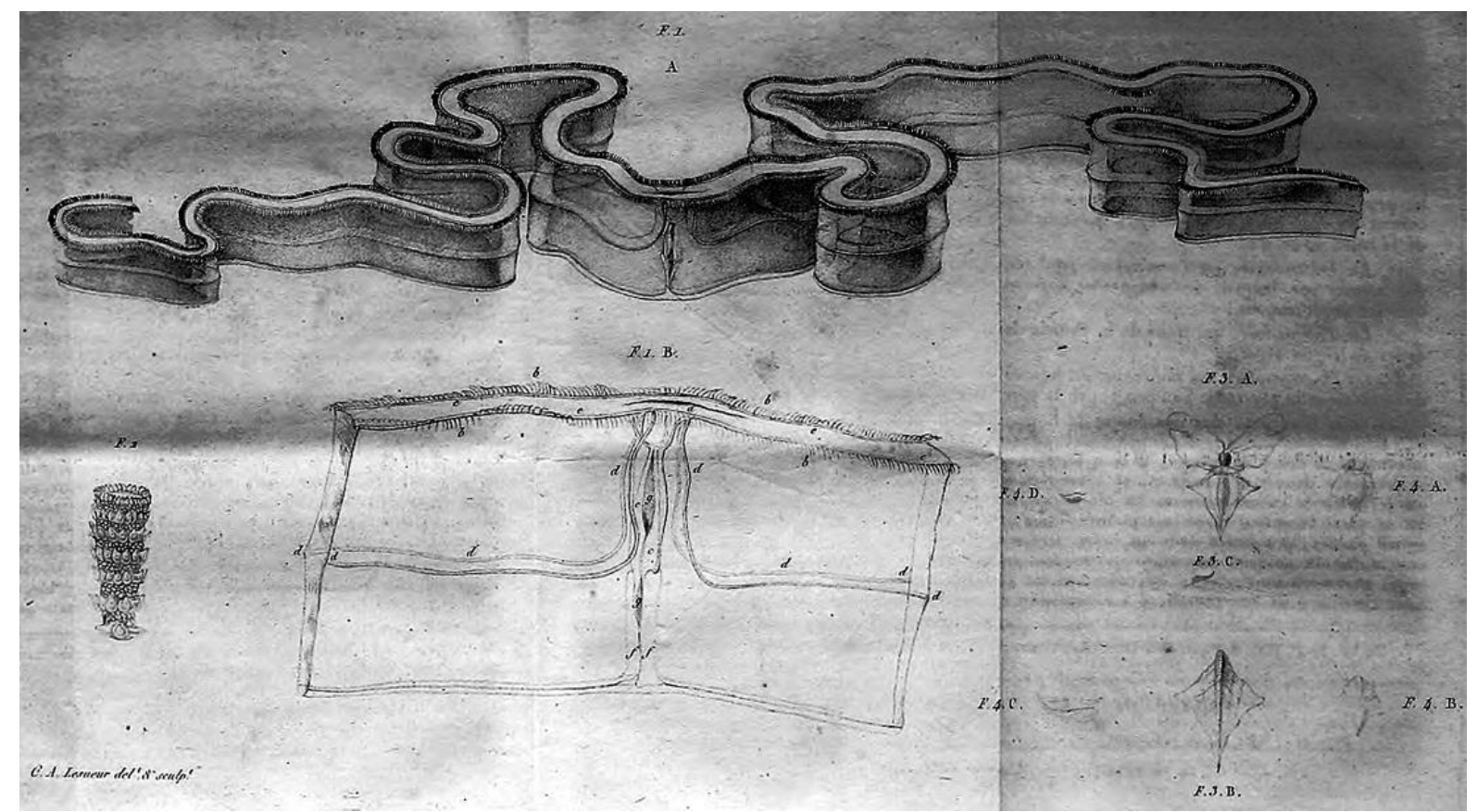

Figure 2. The plate from Lesueur 1813, his first article without Péron. The large organism shown is a gelatinous organism of the marine plankton known a Venus Belt. It can be meters in length. The inscription on the plate indicates that Lesueur was both the artist and engraver of the illustration indicating that he had taught himself copper plate engraving.

In 1815 came the second and final abdication of Napoleon Bonaparte putting into question Lesueur's imperial pension. It was then likely that financial considerations weighed in his decision to travel with, and work for, a wealthy American naturalist and philanthropist, William MacLure, as an illustrator and general assistant. Lesueur met MacLure during May 1815 in Paris, perhaps on the suggestion of Georges Cuvier, and signed a contract agreeing to work as his assistant in his geological explorations in the Americas. Lesueur left Paris named as a corresponding member of the Museum of Natural History with instructions to send specimens to the museum whenever possible. In August 1815 Lesueur sailed from France with MacLure. Although his contract with MacLure was for only two years, Lesueur would not return to France until July of 1837 (Lior 1920).

Lesuer's time in North America can be divided into 4 periods. The first two, relatively brief periods, concern his travels and time as MacLure's assistant. They first explored the Caribbean Islands (1815-1816) and then the Northeastern United States from May 1816 to October 1816 before MacLure and Lesueur finally arrived in Philadelphia. The latter two long periods are his 
Philadelphia period (1816-1825) followed by his time in Harmony, Indiana (1826-1837). The Philadelphia period will be treated below in some detail. As Lesueur's time in New Harmony, his return to France, and final years in Le Havre, have been described previously at great length (i.e., Hamy 1904, Loir 1920, Baglione \& Crémière 2016) these periods will only very briefly summarized here.

Lesueur left Philadelphia in December 1825 as part of a contingent of notable figures of Philadelphia ostensibly to visit a new communal community created by a Scottish philanthropist Robert Owen, in New Harmony Indiana. Supposedly, MacLure, Lesueur and others would visit on the way to conduct explorations of Mexico. The frontier commune, created as a social experiment was severely lacking in the presence of educated people. For reasons still unclear, Lesueur and other Philadelphia naturalists stayed in New Harmony and never returned to Philadelphia. The commune, despite financial aid from MacLure, dissolved in a few years leaving Lesueur and other naturalists more or less marooned but with ample opportunity for collecting and exploration. He traveled to New Orleans multiple times in attempt to obtain some part of his imperial pension, perhaps to finance a return to France. The two color portraits of Lesueur from his period in America, the first from two years after his arrival in Philadelphia, and the other, a few years before his return to France show a remarkable transformation from a French gentleman to an American frontiersman. (Figure 3). He returned to France in 1837, spent 8 years in Paris, and finally settled in his native Le Havre where he was named director of a newly established museum of natural history, housing a large part of his collections. He died in 1846 in Le Havre at age 68.

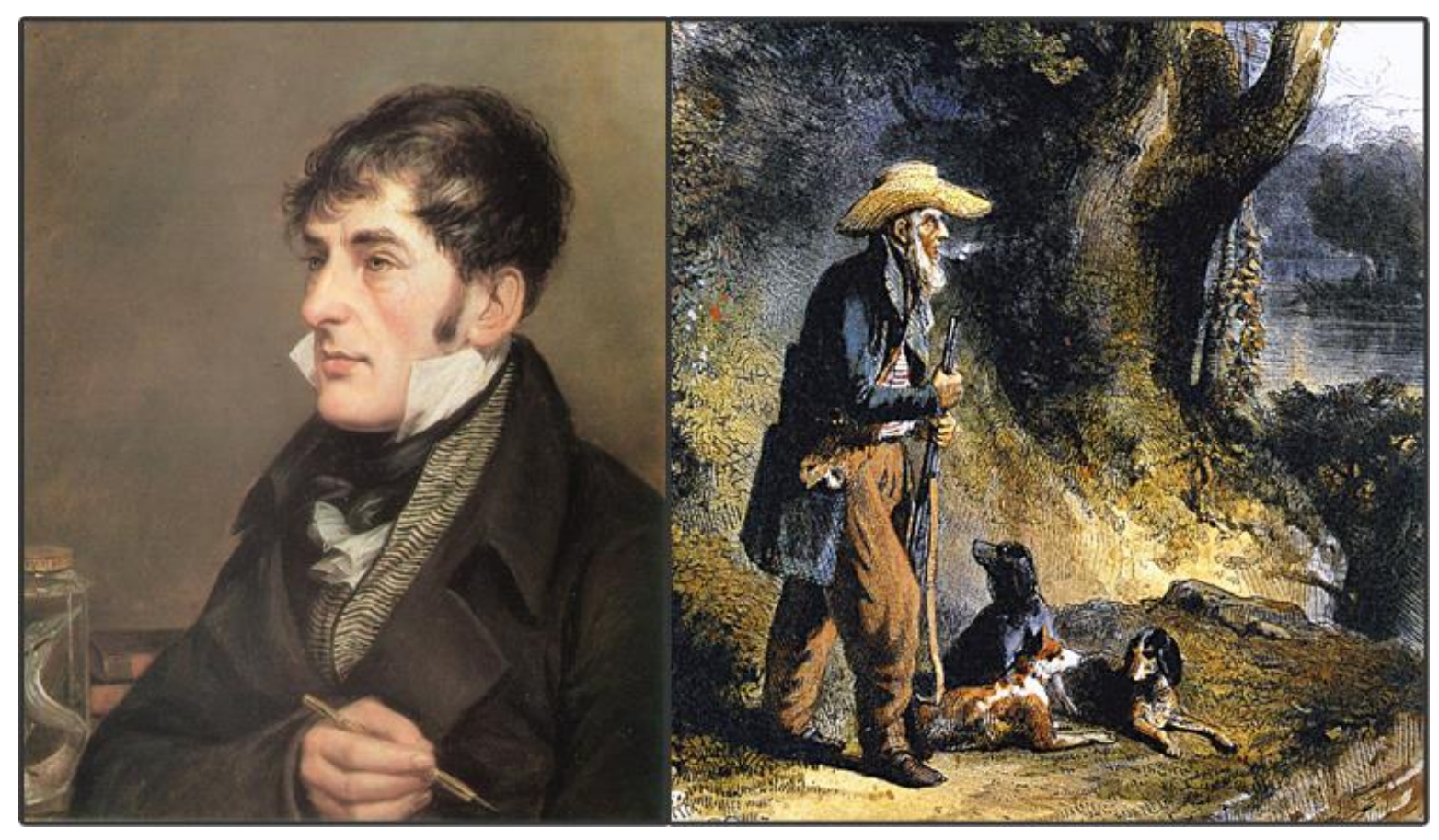

Figure 3. The remarkable transformation of Charles-Alexandre Lesueur in America from a French gentleman to an American frontiersman. Left panel: The 1818 oil portrait of Charles-Alexandre Lesueur by

Charles Wilson Peale (note the pencil in his hand and the preserved fish at his elbow). Right panel: a painting after the 1834 water color by Karl Bodmer, "Lesueur, the Naturalist at New Harmony" (note the long white beard he reportedly would tuck into his shirt).

\section{Lesueur in Philadelphia (1816-1825)}

When he arrived in Philadelphia in October 1816 with MacLure, Lesueur was still under contract to MacLure. Through MacLure, he was introduced to the fledgling Academy of Natural Sciences of Philadelphia, established but a few years earlier by a small group of naturalists. MacLure had been named among the first corresponding members in 1812. Lesueur was warmly welcomed and elected 
as a 'corresponding member', with a professional address in Paris, in December 1816. Lesueur helped the Academy become an international society by proposing several distinguished French naturalists such as Pierre-Andre Latreille and Henri Marie Ducrotay de Blainville, who were elected as corresponding members of Academy in 1817 (Stroud 1995). He quickly formed a close friendship with Thomas Say, the most devoted member of the Academy. Say helped Lesueur by editing his written English and reading aloud his papers for him when they were presented to the Academy. In turn, Lesueur did illustrations and engravings for Say's articles (Stroud 1992). MacLure became a major benefactor to the Academy providing vital financial aid. He was elected president in 1817 and held the position until his death in 1840.

With the support of MacLure, the Academy began publishing the Journal of the Academy of Natural Sciences of Philadelphia. Lesueur was the author of the first article, on pteropods (planktonic molluscs), found when he was with Péron in Nice. It was published in May 1817 and included a plate he engraved (Figure 4). Actually, Lesueur did the engraving for all the plates in the first years of the journal, mostly for his own articles. In the first six issues alone, published in 1817, the illustrations for his articles ranged from the pteropods to stingrays (figure 5), a turtle (figure 6) and jellyfish (figure 7). However, he also provided the illustrations and engraved the plates for articles by other, for example insects, plants and crustaceans (figure 7). Those first 6 issues, up to October 1817, were printed in New York and then distributed from Philadelphia, involving considerable cost as well as back and forth between Philadelphia and New York. In early 1818, the Academy's benefactor and president, MacLure bought a printing press and had it installed in his Philadelphia house so the Journal could be produced entirely in Philadelphia. From then on, Lesueur was involved not with submitting articles and engraving plates but also, along with Thomas Say and other, the actual printing of the Journal.

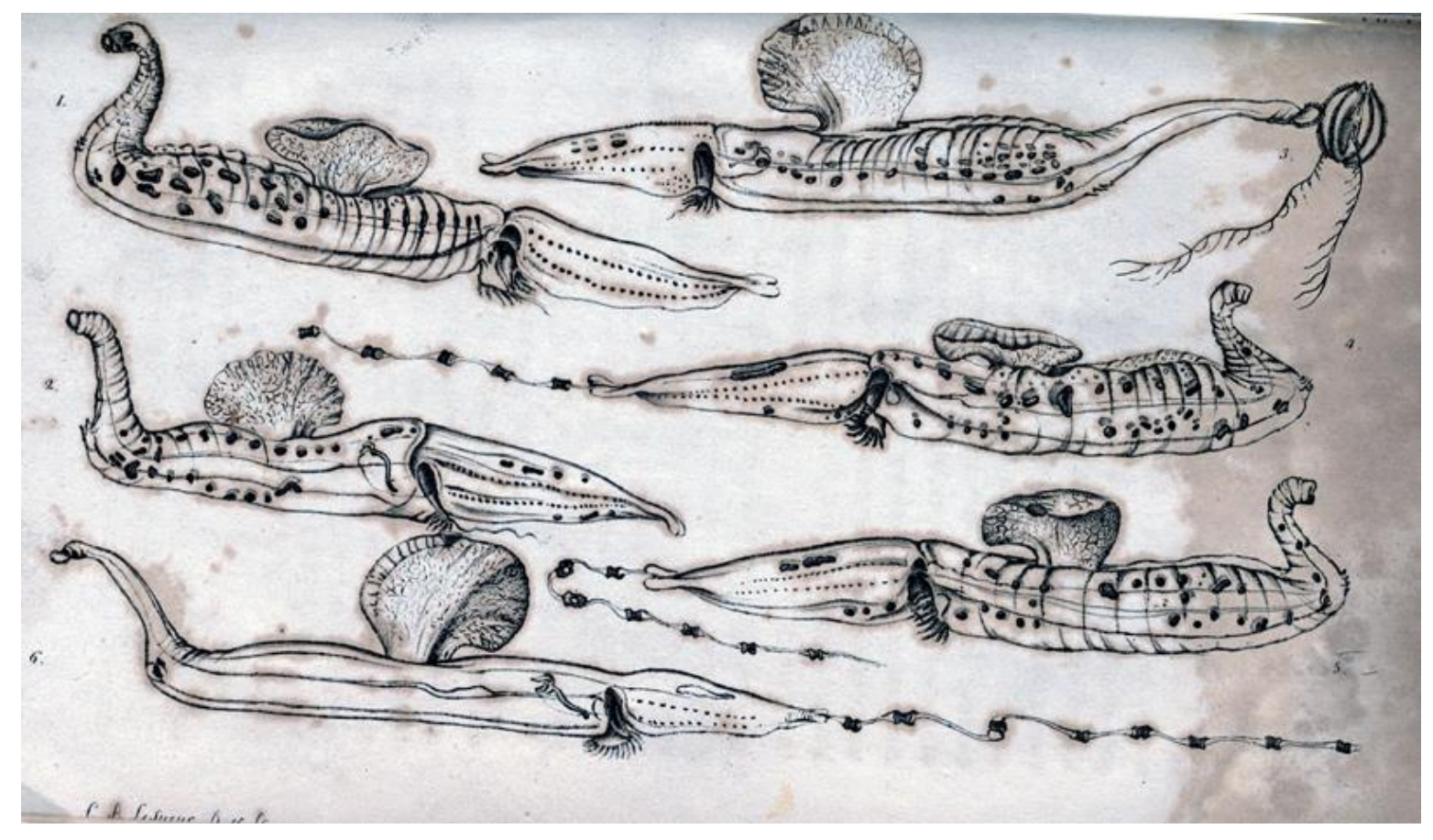

Figure 4. Plate 1 from volume 1, issue 1 of the Journal on pteropods (planktonic molluscs) from the Mediterranean Sea (Le Sueur 1817c). The top right figure shows a pteropod capturing a ctenophore, a gelatinous zooplankter. 


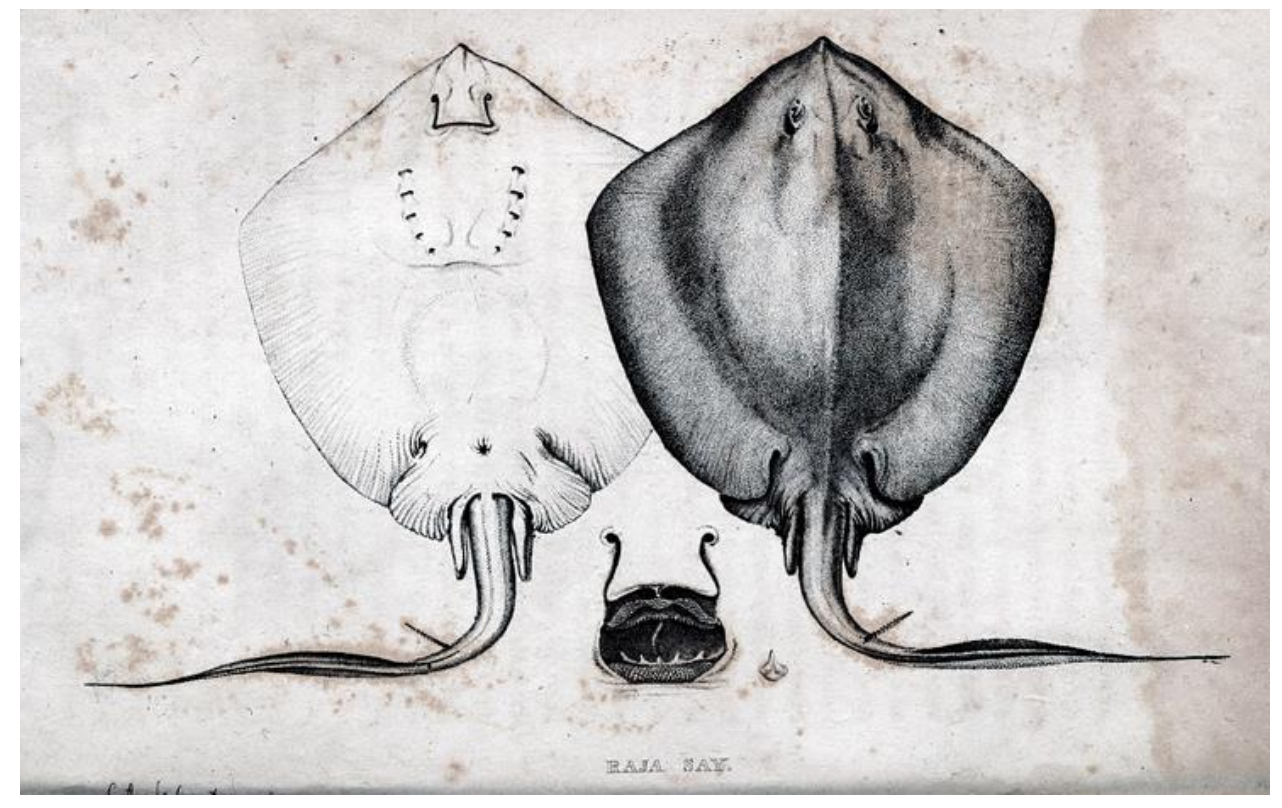

Figure 5. From volume 1, issue 3, a stingray Lesueur (1817e) named for Thomas Say as Raja say, now known as Hypanus say. One of Lesueur's first colored plates; it is that likely he did the coloring himself.

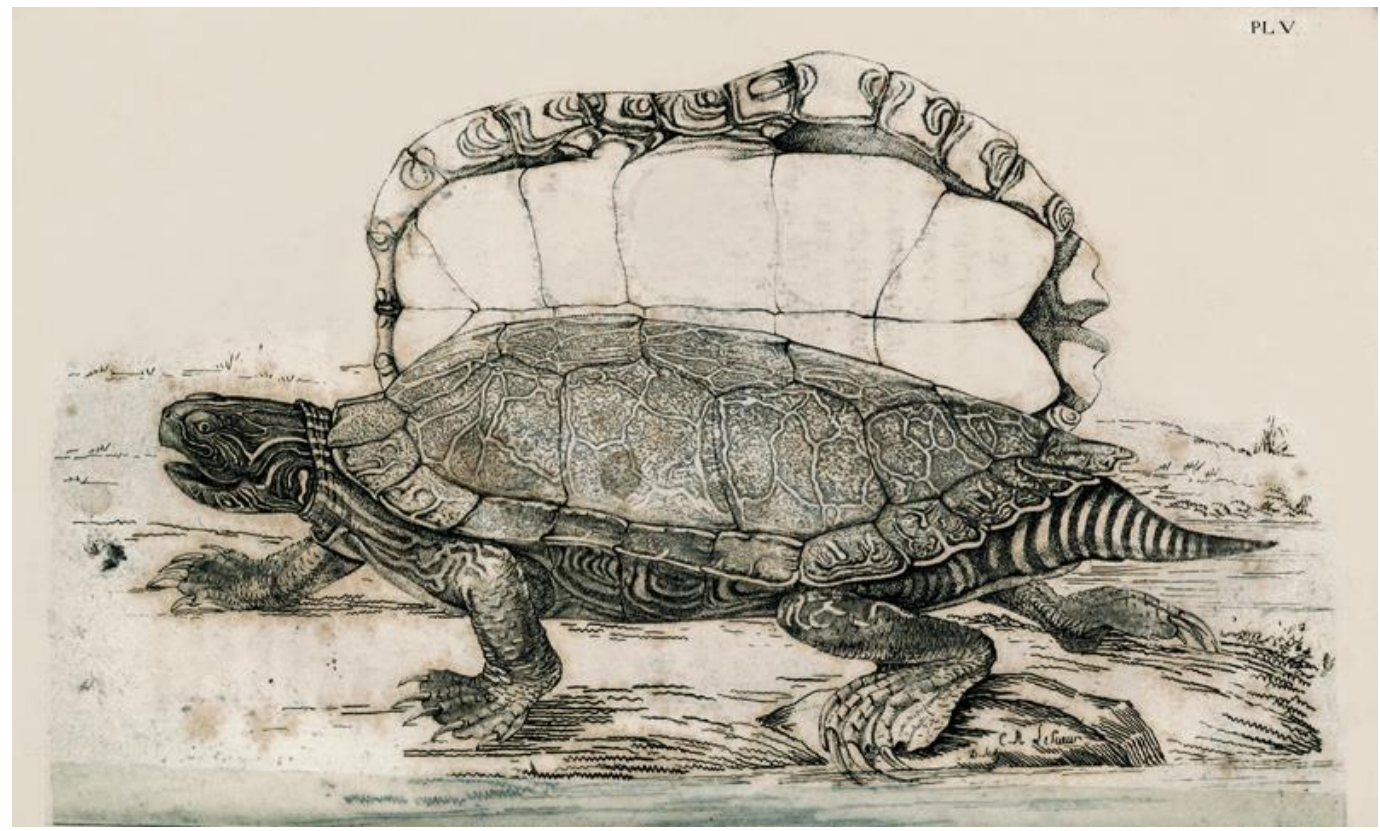

Figure 6. A new turtle: plate 5 in Volume 1 Issue 5 (Le Sueur 1817i). The careful composition, showing the underside of the shell in the background is remarkable. 


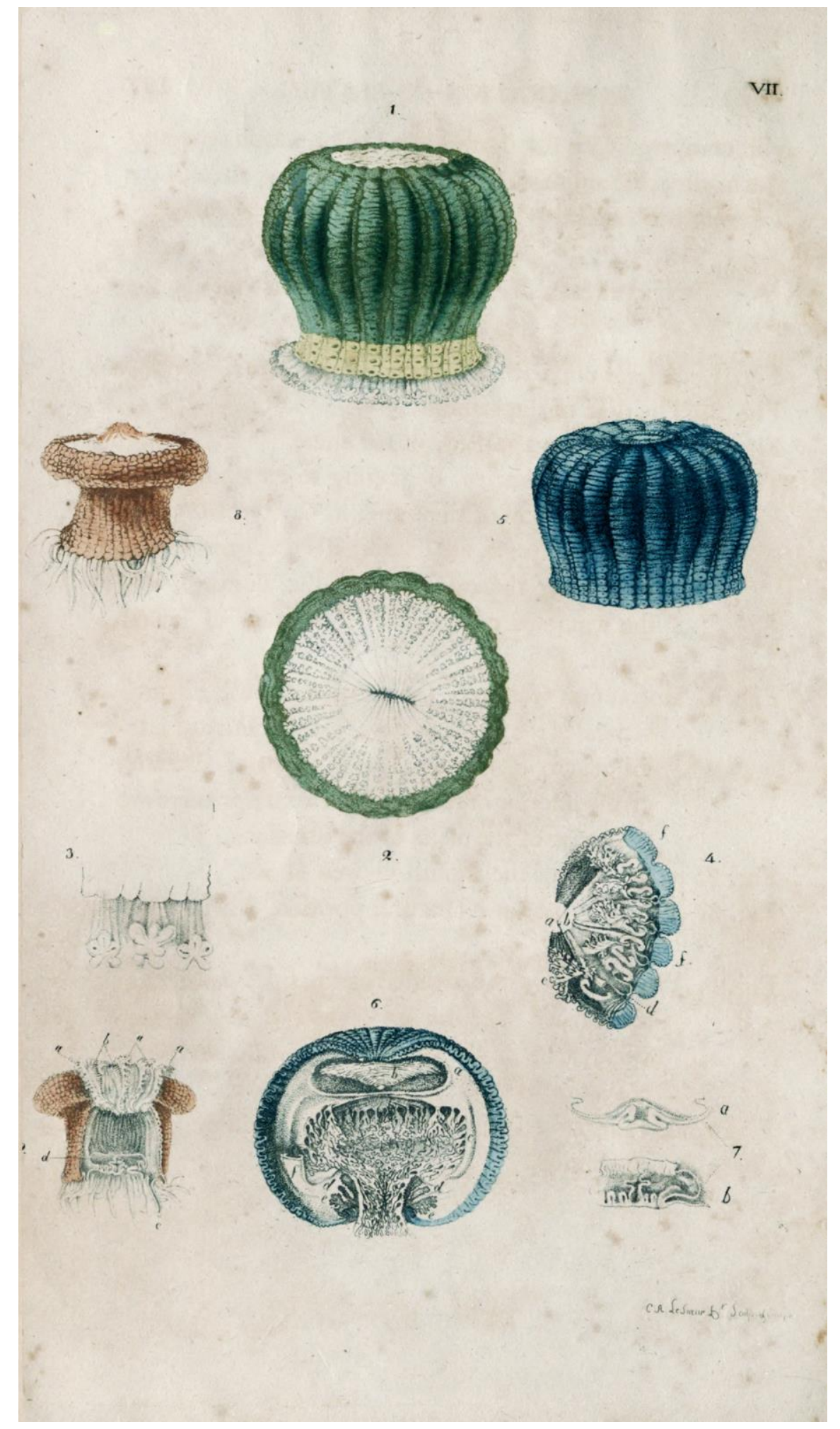

Figure 7. Jellyfish from Volume 1, issue 6, (Le Sueur 1817i), the last issue printed in New York. Lesueur likely did the coloring himself. 


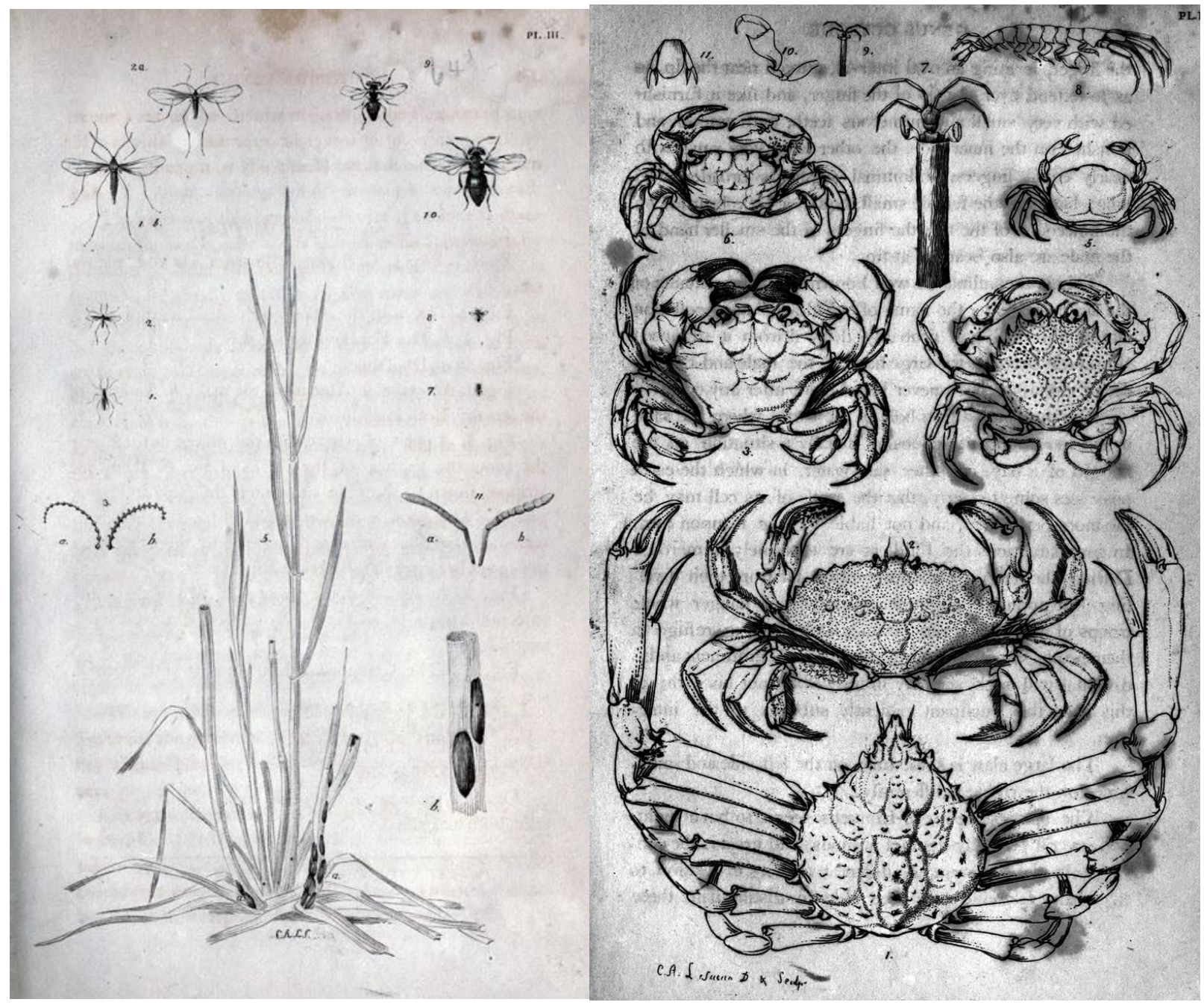

Figure 8. Plates made by Lesueur for articles in the Journal by Thomas Say on insects (Say 1817a) and crustaceans (Say 1817b).

In 1818 Lesueur was freed from his contract with MacLure that meant he no longer drew a salary from MacLure, and was then responsible for his own room and board. His only income was from teaching art. He gave private lessons to young women across the city and also gave regular art lessons in schools, eking out a meager living. However his scientific work continued unabated. Lesueur published his first article in an American journal other the Academy's journal in the Transactions of the American Philosophical Society on several new species of fish (Lesueur 1818a). That same year he was named as a Foreign Member of the society thusly, "Paris, now in Philadelphia". The American Philosophical Society at the time was the most prestigious scientific society, said to be the American equivalent of the Royal Society (Stroud 1992). In 1818 Lesueur was also made one of the Officers of the Academy of Natural Sciences of Philadelphia, a "Curator" along with Thomas Say, Isaiah Lukens and Titian Peale. His contribution to building the reputation of the Academy and it naturalists was considerable. Among the new foreign members named in 1818 were more French naturalists of renown proposed by Lesueur: Cuvier, Lamarck, Jussieu, and Geoffroy-Saint-Hilaire (Stroud 1995; Stroud 2000). The Academy's journal, with Lesueur's articles and illustrations, was widely distributed to, and praised by, important European naturalists (Stroud 1995). The early years in Philadelphia (1817-1818) were Lesueur's most productive period in terms of scientific publications. He published 16 articles, mostly on fish, a large portion of the 38 articles Lesueur published during his years in America (Table One). 
Lesueur, C.A. 1817a. Description de six nouvelles especes de Firoles observees, par MM, Peron et Lesueur dans la mer Mediterranee en 1809, et etablisement du nouveau genre Firoloide

Lesueur, C. A. 1817b. Mémoire sur deux nouveaux genres de mollusques, Atlante et Atlas

Le Sueur, C.A. 1817c. Description of six new species of the genus Firola, observed by Messrs. Le Sueur and Peron in the Mediterranean Sea, in the months of March and April, 1809

Le Sueur, C.A. 1817d. Characters of a new genus, an descriptions of three new species upon which it is formed discovered in the Atlantic Ocean, in the months of March and April, 1816; Lat. 22 9'

Le Sueur, C.A. 1817e. Description of three new species of the genus Raja

Le Sueur, C.A. 1817g. A short description of five (supposed) new species of the genus Muraena, discovered by Mr. Le Sueur, in the year 1816

Le Sueur, C.A. 1817g. Description of two new species of the genus Gadus

Le Sueur, C.A. 1817h. Description of a new species of the genus Cyprinus

Le Sueur, C.A. 1817i. An account of an American species of tortoise, not noticed in the systems

Le Sueur, C.A. 1817j. A new genus of fishes, of the order Abdominales, proposed, under the name of Catostomus and the characters of the genus, with those of it species, indicated

Le Sueur, C.A. 1817k. Descriptions of Four New Species and Two Varieties, of the Genus Hydrargira

Le Sueur, C.A. 1817l. Observations on several species of Actinians

Le Sueur, C.A. 1818a. Description of several species of Chondropterigious Fishes, of North America, with their varieties

Le Sueur, C.A. 1818b. Descriptions of several new species of North American Fishes

Le Sueur, C.A. 1818c. Observations on a new genus of Fossil Shells

Le Sueur, C. A. 1818d. Description of several new species of the genus Esox of North America

Lesueur, C. A. 1819. Notice de quelques poissons découverts dans les lacs du Haut-Canada durant l'été de 1816

Lesueur, C.A. 1821a. Déscription de plusieurs animaux appartenant aux polypiers lamelliferes de M. le Chev. de Lamarck

Le Sueur, C.A. 1821b. Description of a new genus, and of several new species of fresh water fish, indigenous to the United States

Le Sueur, C.A. 1821c. Description of two new species of Exocetus

Lesueur, C.A. 1821d. Descriptions of several new species of cuttle-fish

Lesueur, C.A. 1821e. Observations on several genera and species of fish, belonging to the natural family of the Esoces

Le Sueur, C.A. 1822a. Descriptions of the five new species of the genus Cichla of Cuvier

Lesueur, C.A. 1822b. Description of three new species of the genus Sciaena 


\begin{tabular}{|l|}
\hline Lesueur, C.A. 1822c On the Onykia Angulata \\
\hline Lesueur, C.A. 1822d. Description of a Squalus, of a very large size, which was taken on the coast of \\
\hline Lesueur, C.A. 1823. Descriptions of several new species of Ascidia \\
\hline Lesueur, C.A. 1824a. Descriptions of several new species of Ascidia \\
\hline Lesueur, C.A. 1824b. On three new species of parasitic Vermes, belonging to the Linnæan genus \\
\hline Lesueur, C.A. 1824c. Description of a new species of cephalopod of the genus Loligo \\
\hline Lesueur, C.A. 1824d. Description of two new species of the genus Batrachoid of Lacepede \\
\hline Lesueur, C.A. 1824e. Description of several species of the Linnaean genus Raia of North America \\
\hline Lesueur, C. A. 1824f. Descriptions of several new species of Holothuria \\
\hline Lesueur, C.A. 1825a. Description of two new species of the Linnaean genus Blennius. \\
\hline Lesueur, C.A. 1825b. Description of a new fish of the genus Salmo \\
\hline Lesueur, C.A. 1825c. Descriptions of four new species of Muraenophis \\
\hline Lesueur, C.A. 1825d. Description of a new species of the genus Saurus (Cuvier) \\
\hline Lesueur, C.A. 1827. Note sur deux espéces de tortues du genre Trionyx de M. Geoffroy-Saint-Hilaire \\
\hline
\end{tabular}

Table One. Lesueur's Publications during his Philadelphia period.

Reference in bold denotes an article published in a journal other than the Journal of the Academy of Natural Sciences of Philadelphia. See References for bibliographic details. Lesueur was inconsistent in the spelling of his name, sometimes signing Le Sueur and other times Lesueur.

Lesueur's publications from 1818 contain perhaps his most accomplished scientific illustrations from his time in America. They were printed on the press in MacLure's house. The remarkable illustrations (Figure 9) from his 1818 "Descriptions of several new species of North American Fishes" (Lesueur 1818b) were likely colored by himself. These illustrations led to Lesueur being described as "surely one of the lost lights of American zoological illustration... the "DumerilShark"... is a delicate two-dimensional design that manages to suggest softness and volume, bringing beauty even to the most unlikely subject" (Partidge 1996). 


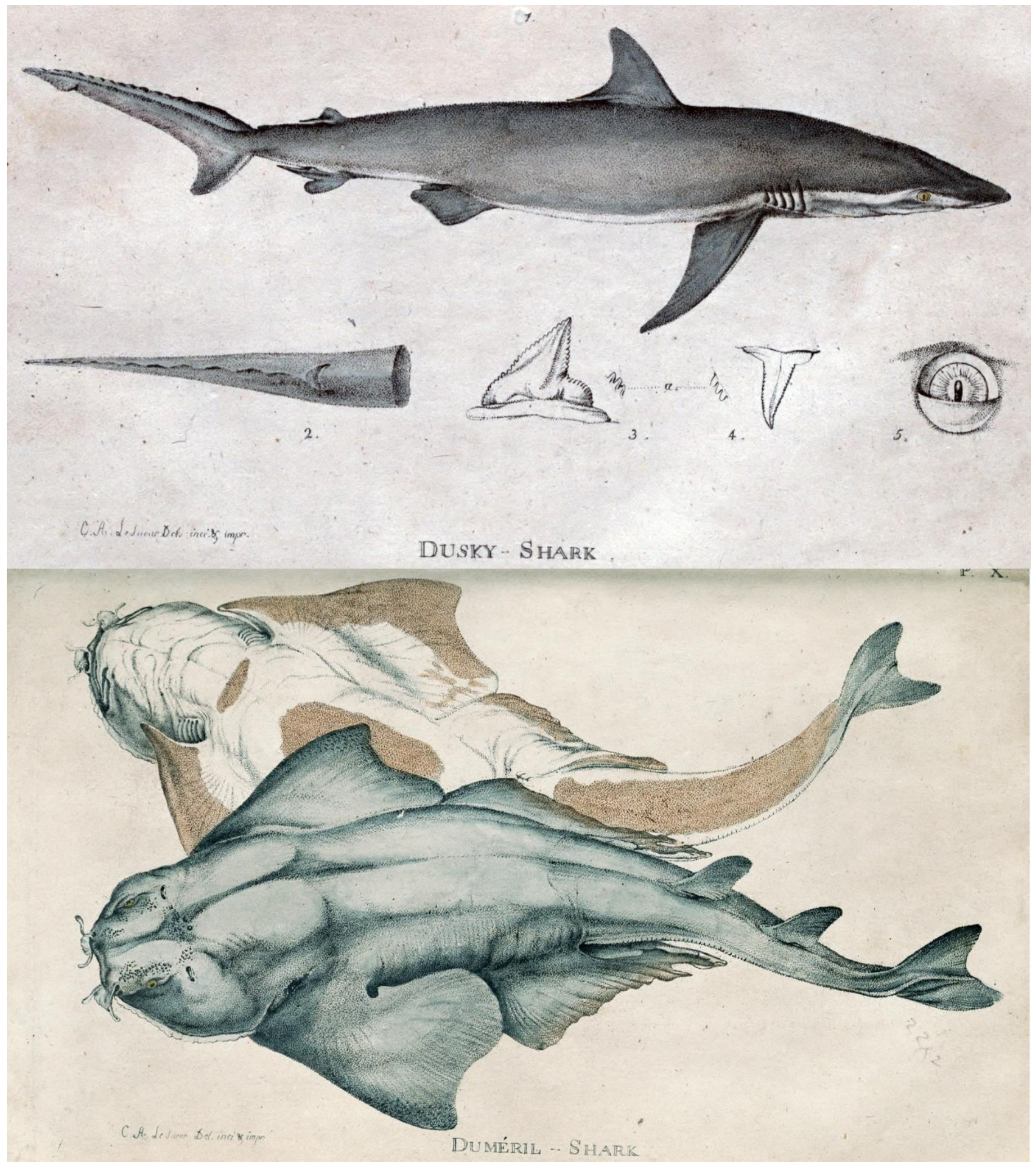

Figure 9. Lesuer's striking illustrations of new species of sharks from his 1818 article in the Journal of the Academy of Natural Sciences of Philadelphia (Le Sueur 1818b). The 'Dusky Shark' is now known as Carcharhinus obscurus and Duméril Shark, named for the French zoologist, is now known as Squatina dumeril.

In the second, 1821 volume of the journal none of Lesueurs's illustrations were in color. Nonetheless, some were remarkable, for example the illustrations of small flying fish and a squid he named for his collegue, Titian Peale (Figure 10). The volume also contains Lesueur's first attempts at lithography, to try to replace engraving copperplates, as a faster and less expensive means to print 
illustrations. The illustration of a fish in Figure 11 is said to be tone of he first uses of lithography in a natural history publication in America (Weimerskirch 1985).

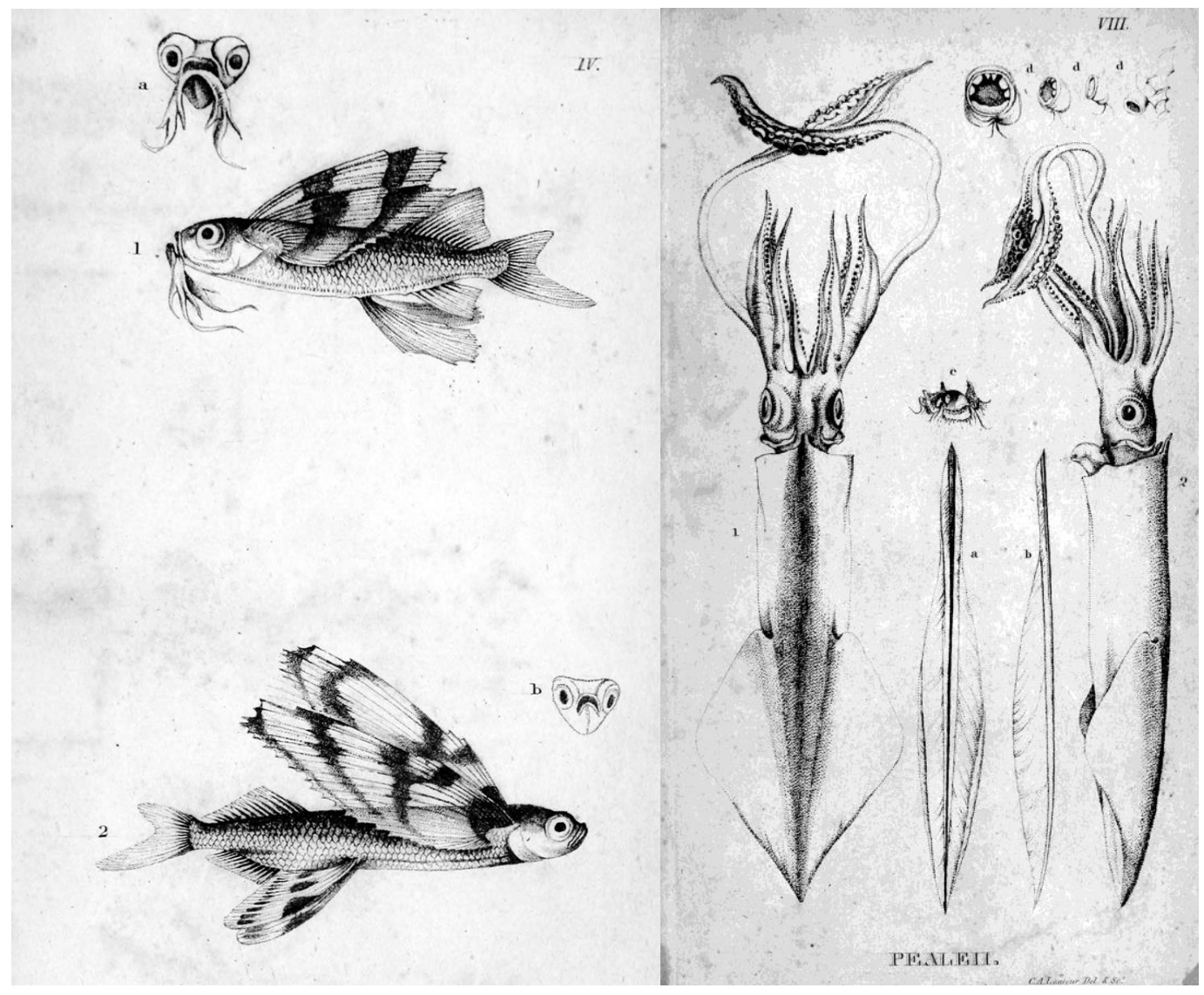

Figure 10. Two plates from Lesueur's articles in the second, 1821 volume. Left panel: flying fish from Lesueur 1821c, Inclusion of "head-on" views in illustrations of fish is unusual. Right panel: a squid named for his fellow curator and scientific illlustrator, Peale, from Lesueur $1821 d$.

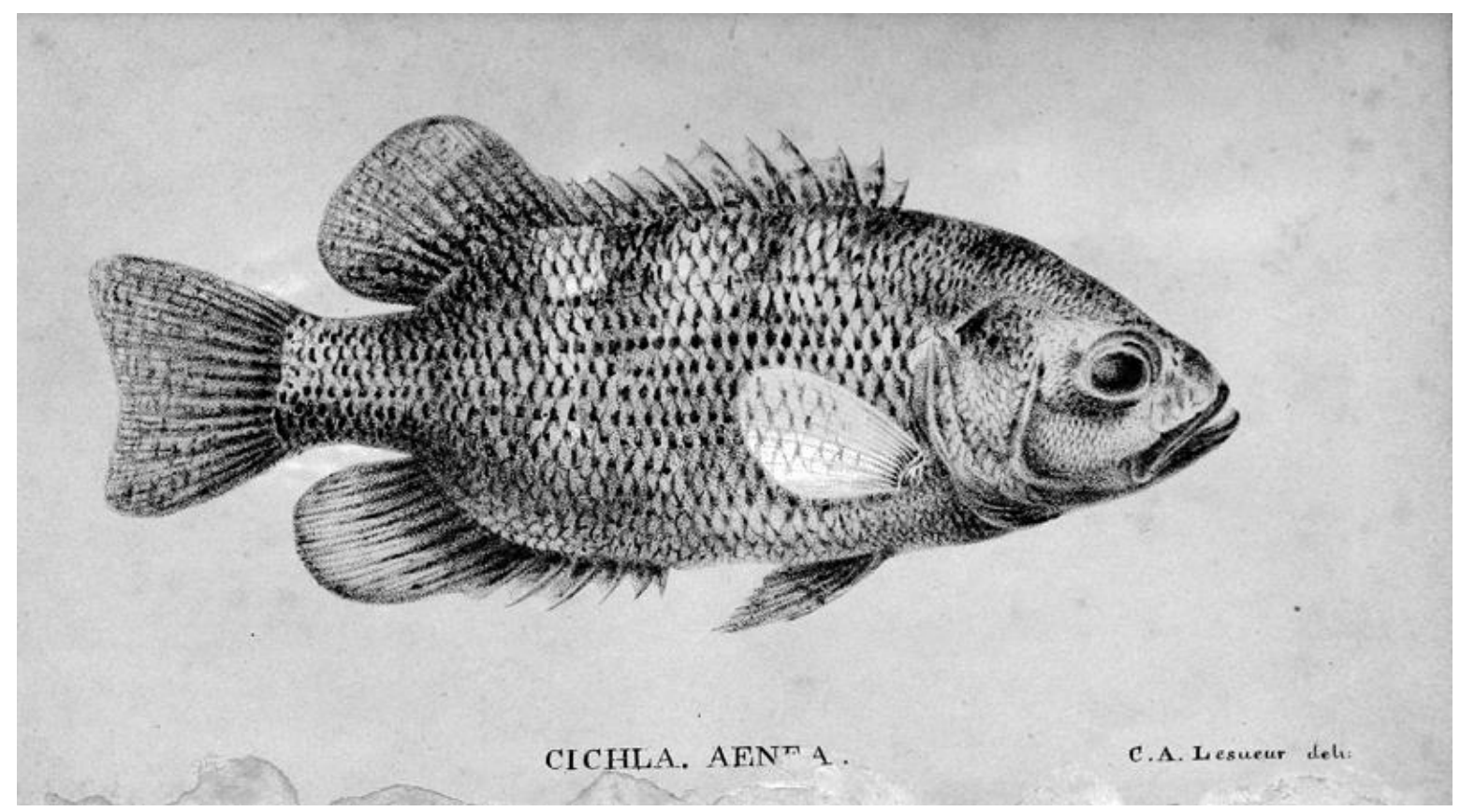

Figure 11. Lesueur experimented with using lithography to replace engraving for the illustrations in the journal. His illustrations of the fish Cichla (Lesueur 1822a) were some of the first lithographs to appear in an American natural history publication. 
Lesueur also provided illustrations for a pioneering work by Say in 1824, "American Entomology", during the Philadelphia period. Say is today known as the 'Father of American Entomology' largely because of his articles on insects but also for his book as the first devoted to insects found in America (Stroud 1992). Although most of the illustrations were by Peale, Lesueur provided the remarkably detailed frontispiece illustration and some of the illustrations (Figure 12), all described as "from nature". The quality of the frontispiece and illustrations were praised in a review of the book in the influential North American Review (e.g. anon. 1825).

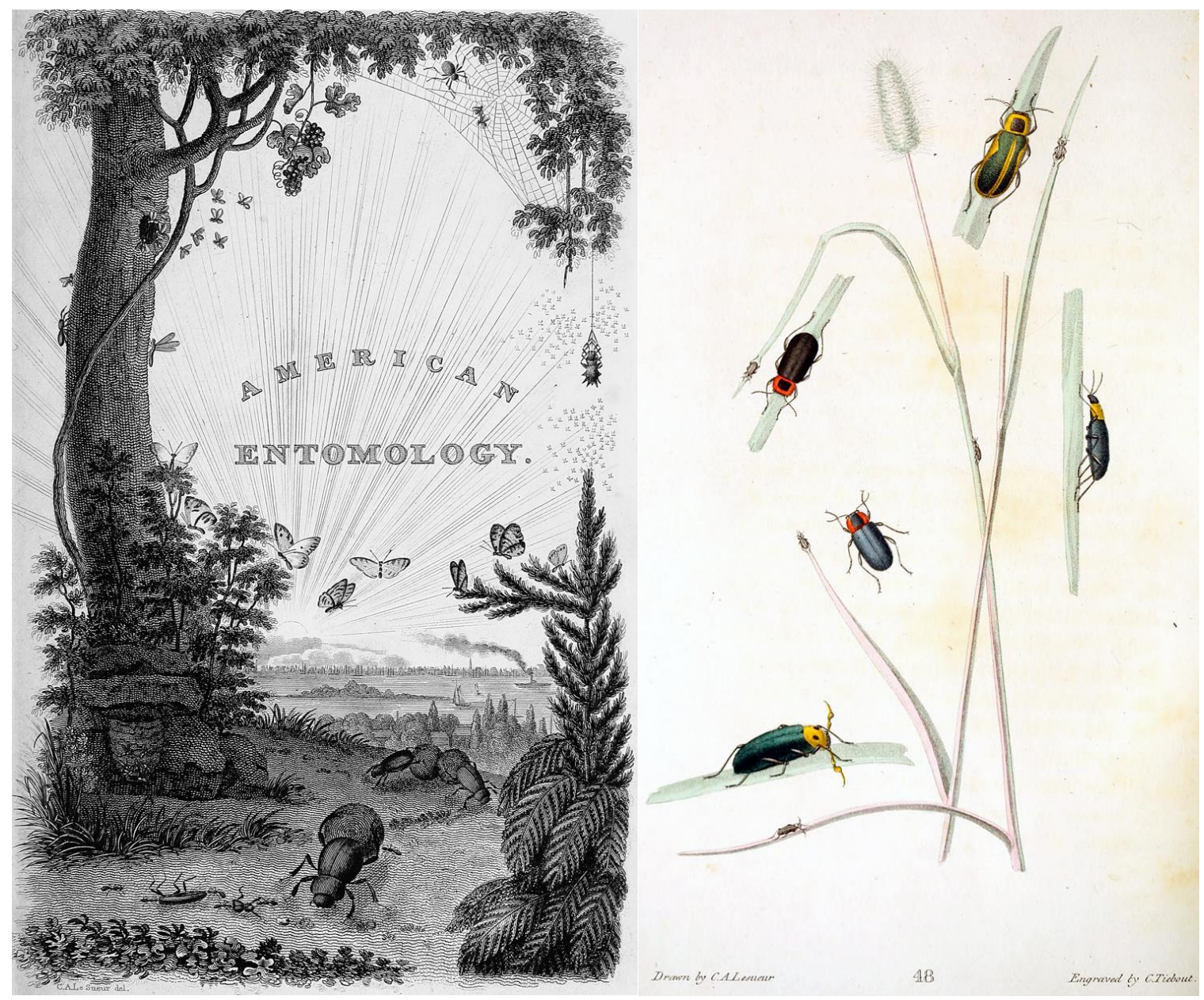

Figure 10. The remarkably detailed frontispiece of American Entomology (Say 1824) by Lesueur (left panel) and one of the plates by Lesueur (right panel). The frontispiece forest scene contains beetles,

butterflies, spiders, termites and ants with Delaware River and the skyline of Philadelphia in the background. The composition is reminiscent of the frontispiece of "Voyages de Découvertes aux Terres Australes" (see Figure 1). The insect plate cleverly shows insects both enlarged to show important details, and actual sizes relative to the plants on which they are found.

During his time in Philadelphia, Lesueur aided not only the development of the Academy but also individuals. Say was named a corresponding member of the Sociéte Philomatique de Paris in 1819, most likely due to a nomination by Lesueur, a full member since 1814. Lesueur appears to have perhaps played a key role in the life of the famous ornithologist John Jay Audubon during his extended stay in Philadelphia. Audubon went to Philadelphia hoping for support, both professional and financial, for his studies and illustrations of the birds of the United States of America. Lesueur admired his paintings and first helped Audubon by getting him a job teaching art at the girl's school at which he himself taught at that time, Marie Fretageot's boarding school. Oddly enough, both Audubon and Lesueur taught drawing there to Lucy Sistar who would later marry Thomas Say and be the colorist of many of his illustrations. Perhaps more important than getting Audubon a job, was Lesueur's advising him on his major project. Lesueur advised Audubon that chances of obtaining 
financial backing for his proposed large artistic book on birds were better by far in Europe than in America as fine arts were not well-appreciated in North America (Stroud 2000). Lesueur also wrote letters of introduction for Audubon to French naturalists that he used in Paris (Audubon 1898). Audubon's famously expensive and out-sized book was eventually published in the United Kingdom, not the United States (Audubon 1831-1838). Although one cannot say with certainty that Audubon's voyages to, and success in, Europe was due in any part to Lesueur, his advice to Audubon turned out to be good advice.

During his Philadelphia period, Lesueur described 193 animals as 'new species'. These were of a surprisingly variety of forms ranging from sea squirts to sharks. Of these, 34 are currently accepted as valid first descriptions and are listed in Table Two. The proportion currently accepted, about $18 \%$ of his species descriptions, recognized today as valid discoveries, is quite respectable for a 19th century naturalist, especially one who worked on very wide range of taxa and lacked access to wellstocked library. For example, Lacepède, the classic fish taxonomist of the Paris Museum of Natural History, described 811 'new species' of which 133 are currently accepted.

\begin{tabular}{|c|c|c|c|}
\hline Species & Type of Organism & Year & Reference \\
\hline Atlanta peronii & mollusc & 1817 & Le Sueur $1817 \mathrm{c}$ \\
\hline Firoloida desmarestia & mollusc & 1817 & Le Sueur 1817d \\
\hline Hypanus say & fish (stingray) & 1817 & Le Sueur $1817 \mathrm{e}$ \\
\hline Anguilla rostrata & fish (eel) & 1817 & Le Sueur $1817 \mathrm{~g}$ \\
\hline Fundulus diaphanus & fish & 1817 & Le Sueur $1817 \mathrm{k}$ \\
\hline Palythoa glareola & invertebrate (coral) & 1817 & Le Sueur $1817 i$ \\
\hline Acipenser brevirostrum & fish & 1818 & Le Sueur $1818 a$ \\
\hline Carcharhinus obscurus & fish (shark) & 1818 & Le Sueur $1818 \mathrm{~b}$ \\
\hline Squatina dumeril & fish (shark) & 1818 & Le Sueur $1818 \mathrm{~b}$ \\
\hline Coregonus artedi & fish & 1818 & Le Sueur $1818 \mathrm{~b}$ \\
\hline Dorosoma cepedianum & fish & 1818 & Le Sueur $1818 \mathrm{~b}$ \\
\hline Opisthonema oglinum & fish & 1818 & Le Sueur $1818 \mathrm{~b}$ \\
\hline Ameiurus nebulosus & fish (catfish) & 1819 & Lesueur 1819 \\
\hline Poecilia latipinna & fish & 1821 & Le Sueur $1821 \mathrm{~b}$ \\
\hline Doryteuthis pealeii & squid & 1821 & Le Sueur $1821 \mathrm{~d}$ \\
\hline Illex illecebrosus & squid & 1821 & Le Sueur $1821 \mathrm{~d}$ \\
\hline Leachia cyclura & squid & 1821 & Le Sueur $1821 \mathrm{~d}$ \\
\hline Ommastrephes bartramii & squid & 1821 & Le Sueur 1821d \\
\hline Onykia carriboea & squid & 1821 & Le Sueur $1821 \mathrm{~d}$ \\
\hline Taonius pavo & squid & 1821 & Le Sueur $1821 \mathrm{~d}$ \\
\hline Hemiramphus balao & fish (needlefish) & 1821 & Le Sueur $1821 \mathrm{e}$ \\
\hline Hyporhamphus erythrorinchus & fish (needlefish) & 1821 & Le Sueur $1821 \mathrm{e}$ \\
\hline
\end{tabular}




\begin{tabular}{|l|l|l|l|}
\hline Platybelone argalus & fish (needlefish) & 1821 & Le Sueur 1821e \\
\hline Galeocerdo cuvier & fish (shark) & 1822 & Lesueur 1822d \\
\hline Styela plicata & invertebrate (sea squirt) & 1823 & Lesueur 1823 \\
\hline Lernaeenicus radiatus & crustacean (copepod) & 1824 & Lesueur 1824b \\
\hline Hypanus sabinus & fish (stingray) & 1824 & Lesueur 1824e \\
\hline Myliobatis freminvillei & fish (stingyray) & 1824 & Lesueur 1824e \\
\hline Sclerodactyla briareus & echinoderm & 1824 & Lesueur 1824f \\
\hline Synaptula hydriformis & echinoderm & 1824 & Lesueur 1824f \\
\hline Halophryne diemensis & fish & 1824 & Lesueuer 1824d \\
\hline Hypsoblennius hentz & fish & 1825 & Lesueur 1825a \\
\hline Myrichthys ocellatus & fish (eel) & 1825 & Lesueur 1825c \\
\hline Uropterygius macularius & fish (eel) & 1825 & Lesueur 1825c \\
\hline
\end{tabular}

Table Two. Species described by Charles-Alexandre Lesueur during his Philadelphia years, which are currently accepted as valid first descriptions.

\section{Conclusion}

Despite being periodically listed as an important figure in the development of science in general, and natural history in particular, in the United States, Lesueur's work as a scientist is not well known. Here the reasons why he has been considered an important figure have hopefully been made apparent. He not only described many new animals, he described them using truly remarkable illustrations. Furthermore, he lent his artistic talents to others and played a large role in the establishment of one the most important scientific societies in United States.

\section{References}

Audubon, J.J. 1831-1839. Ornithological biography, or an account of the habits of the birds of the United States of America; accompanied by descriptions of the objects represented in the work entitled The Birds of America, and interspersed with delineations of American scenery and manners. Edinburgh: Adam Black.

Audubon, M.R. 1898. Audubon and his journals. London: John C. Nimmo, Vol 1.

Baglione, G., Crémière, C. 2016. Charles-Alexandre Lesueur painter and naturalist: a forgotten treasure. Le Havre: Editions du Muséum d'Histoire Naturelle du Havre.

Baudin, N. 2000. Mon voyage aux Terres australes, le journal personnel du commandant Baudin. ( ed. Jacqueline Bonnemains), Paris: Imprimerie nationale.

Blum, A.S. 1993. Picturing Nature: American Nineteenth-century zoological illustration. Princeton: Princeton University Press.

Chappey, J. L. (2010). Des naturalistes en Révolution: les procès-verbaux de la Société d'histoire naturelle de Paris (1790-1798). Paris: Editions du Comité des travaux historiques et scientifiques.

Cuvier, G., A. Valenciennes, A. 1828. Histoire naturelle des poissons. Vol 1. Levrault, Paris.

Deleuze, J.P.F. 1816. Eloge historique de François Péron. In Peron, F. , Freycinet, L., Voyage de Décourvertes aux Terres Australes. Historique, Vol. 2, Paris, Imprimerie Royale, pp 434-457.

Duyker, E. 2006. François Péron: an impetuous life, naturalist and voyager. Victoria: The Miegunyah Press. 
Hamy, E.T. 1904. Les voyages du Naturaliste Ch. Alex. Lesueur dans l'Amerique du Nord (1815-1837). Journal de la Sociéte des Américanistes de Paris, 5:1- 111.

Jackson, J.J., Kimler, W.C. 1999. Taxonomy and the personal equation: the historical fates of Charles Girad and Louis Agassiz. Journal of the History of Biology 32:509-555.

Lesueur, C.A. 1813. Mémoire sur quelques nouvelles espèces d'animaux mollusques et radiare recueillis dans la Méditerranée, près de Nice. Nouveau Bulletin des Sciences, 3:281-285.

Lesueur, C.A. 1814. Note sur deux poissons non encore décrits du genre Callionyme et de l'ordre des Jugulaires. Bulletin de la Société Philomatique, 1:5-6.

Lesueur, C.A. 1817a. Description de six nouvelles especes de Firoles observees, par MM, Peron et Lesueur daus la mer Mediterranee en 1809, et etablisement du nouveau genre Firoloide. Bulletin des Sciences par la Société Philomatique de Paris, 2:157-160.

Lesueur, C. A. 1817b. Mémoire sur deux nouveaux genres de mollusques, Atlante et Atlas. Journal de Physique, 85:390-393.

Le Sueur, C.A. 1817c. Description of six new species of the genus Firola, observed by Messrs. Le Sueur and Peron in the Mediterranean Sea, in the months of March and April, 1809. Journal of the Academy of Natural Sciences of Philadlphia, 1:3-8.

Le Sueur, C.A. 1817d. Characters of a new genus, an descriptions of three new species upon which it is formed; discovered in the Atlantic Ocean, in the months of March and April, 1816; Lat. 22 9'. Journal of the Academy of Natural Sciences of Philadelphia, 1:37-41.

Le Sueur, C.A. 1817e. Description of three new species of the genus Raja. Journal of the Academy of Natural Sciences of Philadelphia, 1:41-45.

Le Sueur, C.A. 1817g. A short description of five (supposed) new species of the genus Muraena, discovered by Mr. Le Sueur, in the year 1816. Journal of the Academy of Natural Sciences of Philadelphia, 1:81-83

Le Sueur, C.A. 1817g. Description of two new species of the genus Gadus. Journal of the Academy of Natural Sciences of Philadelphia, I:83-85

Le Sueur, C.A. 1817h. Description of a new species of the genus Cyprinus. Journal of the Academy of Natural Sciences of Philadelphia, I:85-86.

Le Sueur, C.A. 1817i. An acount of an American species of tortoise, not noticed in the systems. Journal of the Academy of Natural Sciences of Philadelphia, I:86-88.

Le Sueur, C.A. 1817j. A new genus of fishes, of the order Abdominales, proposed, under the name of Catostomus ; and the characters of the genus, with those of it species, indicated. Journal of the Philadelphia Academy of Natural Sciences, 1:88-96;102-111.

Le Sueur, C.A. 1817k. Descriptions of Four New Species and Two Varieties, of the Genus Hydrargira. Journal of the Academy of Natural Sciences of Philadelphia, 1:126-134.

Le Sueur, C.A. 18171. Observations on several species of Actinians. Journal of the Academy of Natural Sciences of Philadelphia, I:149-154; 169-188.

Le Sueur, C.A. 1818d. Description of several species of Chondropterigious Fishes, of North America, with their varieties. Transactions of the American Philosophical Society; New Series, 1:383-394

Le Sueur, C.A. 1818a. Descriptions of several new species of North American Fishes. Journal of the Academy of Natural Sciences of Philadelphia 1:222-235; 359-368.

Le Sueur, C.A. 1818b. Observations on a new genus of Fossil Shells. Journal of the Academy of Natural Sciences of Philadelphia, 1:310-313.

Le Sueur, C.A. 1818c. Description of several new species of the genus Esox of North America. Journal of the Academy of Natural Sciences of Philadelphia, 1:413-417.

Lesueur, C.A. 1819. Notice de quelques poissons découverts dans les lacs du Haut-Canada durant l'été de 1816. Mémoires du Muséum d'Histoire naturelle, 5:148-161.

Lesueur, C.A. 1821a. Déscription de plusieurs animaux appartenant aux polypiers lamelliferes de M. le Chev. de Lamarck. Mémoires du Muséum d'Histoire naturelle, 6, 271-298. 
Le Sueur 1821b. Description of a new genus, and of several new species of fresh water fish, indigenous to the United States. Journal Academy Natural Sciences Philidelphia 2:2-8.

Le Sueur, C.A. 1821c. Description of two new species of Exocetus. Journal Academy Natural Sciences Philidelphia 2:8-11.

Lesueur, C.A. 1821d. Descriptions of several new species of cuttle-fish. Journal Academy Natural Sciences Philidelphia 2:86-101.

Lesueur, C.A. 1821e. Observations on several genera and species of fish, belonging to the natural family of the Esoces. Journal Academy Natural Sciences Philidelphia 2:124-138.

Le Sueur, C.A. 1822a. Descriptions of the five new species of the genus Cichla of Cuvier. Academy of Natural Sciences of Philadelphia Journal 2:214-221

Lesueur, C.A. 1822b. Description of three new species of the genus Sciaena. Journal of the Academy of Natural Sciences of Philadelphia, 2:251-256.

Lesueur, C.A. 1822c On the Onykia Angulata. Journal of the Acdemay of Natural Sciences of Philadelphia, 2:296299.

Lesueur, C.A. 1822d. Description of a Squalus, of a very large size, which was taken on the coast of New Jersey. Journal of the Academy of Natural Sciences of Philadelphia, 2:343-352

Lesueur, C. A. 1823. Descriptions of several new species of Ascidia. Journal of the Academy of Natural Sciences of Philadelphia, 3:2-8.

Lesueur, C.A. 1824a. Descriptions of several new species of Ascidia. The Philosophical Magazine, 63(313):321-325.

Lesueur, C.A. 1824b. On three new species of parasitic Vermes, belonging to the Linnæan genus Lernæa. Journal of the Academy of Natural Sciences of Philadelphia, 3:286-293.

Lesueur, C.A. 1824c Description of a new species of cephalopod of the genus Loligo. Journal of the Academy of Natural Sciences of Philadelphia, 3:282-284.

Lesueur, C.A. 1824d. Description of two new species of the genus Batrachoid of Lacepede. Journal of the Academy of Natural Sciences of Philadelphia, 3:395-403

Lesueur, C.A. 1824e. Description of several species of the Linnaean genus Raia of North America. Journal of the Academy of Natural Sciences of Philadelphia, 4:100-121.

Lesueur, C.A. 1824f. Descriptions of several new species of Holothuria. Journal of the Academy of Natural Sciences of Philadelphia, 4:155-163.

Lesueur, C. 1825a. Description of two new species of the Linnaean genus Blennius. Journal of the Academy of Natural Sciences of Philadelphia, 4: 361-364.

Lesueur, C.A. 1825b. Description of a new fish of the genus Salmo. Journal of the Academy of Natural Sciences of Philadelphia., 5:48-51.

Lesueur, C.A. 1825c. Descriptions of four new species of Muraenophis. Journal of the Academy of Natural Sciences of Philadelphia, 5, 107-109.

Lesueur, C.A. 1825d. Description of a new species of the genus Saurus (Cuvier). Journal of the Academy of Natural Sciences of Philadelphia, 5:118-119.

Lesueur, C.A., Petit, N.M. 1811. Voyage de découvertes aux terres australes, exécuté par ordre de S.M. l'empereur et roi. Atlas Part 1.

Loir, Mme. A. 1920. Charles-Alexandre Lesueur, artiste et savant français en Amérique de 1816 à 1839. Le Havre: Muséum d'Histoire Naturelle, 108 pp.

Martin, R. 1998. Le rêve australien de Napoléon, Description et projet secret de conquête française. Revue de l'Institut Napoléon, $\mathrm{n}^{\circ} 176,187 \mathrm{pp}$.

Meyers, G.S. 1964. A brief sketch of the history of ichthyology in America to the year 1850. Copeia, 1964:33-41.

Pinault, M. 1990. Le Peintre et l'histoire naturelle. Paris: Flammarion.

Say, T. 1817a. Some Account of the Insect known by the name of Hessian Fly, and of a parasitic Insect that feeds on it. Journal of the Academy of Natural Sciences of Philadelphia, 1:45-49. 
Say, T. 1817b. An Account of the Crustacea of the United States Journal of the Academy of Natural Sciences of Philadelphia, 1: 57-81;155-169

Struik, D.J. 1959. American science between 1780 and 1830. Science 129:1100-1106.

Stroud, P.T. 1992. Thomas Say, new world naturalist. Philadelphia: University of Pennsylvania Press.

Stroud, P.T. 1995. The founding of the Academy of Natural Sciences of Philadelphia in 1812 and its Journal in 1817. Archives of Natural History, 22:221-133.

Stroud, P.T. 2000. The Emperor of nature: Charles-Lucien Bonaparte and his world. Philadelphia: University of Pennsylvania Press.

Weimerskirch, P.J. 1985. Naturalists and the beginnings of lithography in America. in Wheeler, A. , Price, JH. (eds) From Linnaeus to Darwin: commentaries on the history of biology and geology: papers from the fifth Easter Meeting of the Society for the History of Natural History, 28-31 March, 1983, "Natural history in the early nineteenth century" London: Society for the History of Natural History, pp 167-177.

Youmans, W.J. 1896. Pioneers of science in America: sketches of their lives and scientific work. New York: Applelton. 